\title{
Effect of different nutrient resources on yield and quality of basmati/aromatic rice in inceptisol of Eastern Uttar Pradesh
}

\author{
S. F. A. ZAIDI, SURESH KUMAR, RAM BHAROSE, RAJESH KUMAR, GOVIND SINGH AND K. K. VERMA
}

Received : 30.12.2015; Revised : 27.04.2016; Accepted : 23.05.2016

\section{MEMBERS OF RESEARCH FORUM:}

Corresponding author : S. F. A. ZAIDI, Department of Soil Science and Agricultural Chemistry College of Agriculture, N. D. University of Agriculture and Technology, Kumarganj, FAIZABAD (U.P.) INDIA

Co-authors :

SURESH KUMAR, RAM BHAROSE, RAJESH KUMAR, GOVIND SINGH AND K. K. VERMA, Department of Soil Science and Agricultural Chemistry, College of Agriculture, N. D. University of Agriculture and Technology, Kumarganj, FAIZABAD (U. P.) INDIA

\section{Summary}

A field experiment was conducted at Crop Research Station, Masodha under Narendra Deva University of Agriculture and Technology, Kumarganj, Faizabad, (U.P.) during Kharif season 2008-2009 to evaluate the productivity and quality of aromatic/basmati rice variety under different nutrient parameters which included the application of nutrients through only chemical fertilizer, only organic source and combination of organic manure and fertilizer, besides the foliar spray of a plant growth retardant (Cycocel) in combination with inorganic fertilizer to reduce plant height. An improved basmati variety vasumathi, a traditional culture, tarori basmati and local non-basmati aromatic rice, Kalanamak were included as a test variety. A significant response of different nutrient resources @ 100:50:50 kg NPK ha-1 on rice production and their quality was observed. Use of inorganic fertilizer with cycocel produced maximum grain $\left(3.77 \mathrm{t} \mathrm{ha}^{-1}\right)$ and straw $\left(5.93 \mathrm{t} \mathrm{ha}^{-1}\right)$ yield followed by inorganic fertilizer alone treatment which recorded 3.68 grain and 5.32 straw yield $\mathrm{t} \mathrm{ha}^{-1}$. Organic sources applied alone produced minimum grain $\left(3.31 \mathrm{t} \mathrm{ha}^{-1}\right)$ and straw $\left(4.94 \mathrm{tha}^{-1}\right)$ whereas integrated use of organic and inorganic fertilizer treatment significantly improved grain $\left(3.60 \mathrm{t} \mathrm{ha}^{-1}\right)$ and straw $\left(5.03 \mathrm{t} \mathrm{ha}^{-1}\right)$ over organic treatment alone. Among varieties, the improved basmati (Vasumathi) recorded higher grain $\left(3.76 \mathrm{t} \mathrm{ha}^{-1}\right)$ and straw $\left(4.62 \mathrm{t} \mathrm{ha}^{-1}\right)$ yield than traditional tarori basmati which recorded $2.30 \mathrm{t}$ grain/ha and $4.04 \mathrm{t}$ straw/ ha. Whereas maximum grain $\left(4.01 \mathrm{t} \mathrm{ha}^{-1}\right)$ and straw $\left(5.18 \mathrm{t} \mathrm{ha}^{-1}\right)$ yield was produced by non-basmati aromatic variety Kalanamak. The influence of nutrients sources on grain quality was significant for kernel dimensions, amylase content and gell consistency. Organic sources in general, were superior to fertilizers in improving grain and the quality parameters and recorded maximum hilling (78.6\%), millimg (67.79\%), KL (6.74mm), KB (1.84mm), amylase content 26 per cent and gell consistency $(61.6 \mathrm{~mm})$. Among varieties, improved basmati (Vasumathi) recorded maximum hilling (79.5\%) and milling (68.6\%) fallowed by Kalanamak which recorded 78.2 per cent hulling and 67.6 per cent milling. The minimum grain quality parameters were recorded by traditional tarori basmati grown in Inceptisol of Eastern U.P.

Key words : Basmati rice, Aromatic rice, INM in rice production

How to cite this article : Zaidi, S. F. A., Kumar, Suresh, Bharose, Ram, Kumar, Rajesh, Singh, Govind and Verma, K. K. (2016). Effect of different nutrient resources on yield and quality of basmati/aromatic rice in inceptisol of Eastern Uttar Pradesh. Asian J. Soil Sci., 11 (1) : 230-234 : DOI : 10.15740/HAS/ AJSS/11.1/230-234. 